\title{
KANDUNGAN TIMBAL (Pb) DAN STRUKTUR HISTOLOGI LAMBUNG IKAN MUJAIR (Oreochromis mossambicus) YANG HIDUP DI PERAIRAN UPAL PT. ITDC
}

\section{LEAD (Pb) CONTENT AND STOMACH HISTOLOGICAL STRUCTURE IN TILAPIA (Oreochromis mossambicus) FISH ORGANS IN THE WATERS OF UPAL PT. ITDC}

\author{
Shanon Lestari, Ngurah Intan Wiratmini' Job Nico Subagio \\ Program Studi Biologi Fakultas Matematika dan Ilmu Pengetahuan Alam \\ Universitas Udayana \\ Bukit Jimbaran \\ Email : shanonlestari@gmail.com
}

\begin{abstract}
ABSTRAK
Nusa Dua merupakan kawasan pariwisata dengan rancang bangun yang komprehensif dan terpadu sebagai sarana akomodasi wisata berkelas Internasional. Pengelolaan limbah cair dikelola secara terpadu pada Unit Pengelolaan Air Limbah (UPAL) milik PT. ITDC. Hotel hotel membuang limbah cairnya melalui collection pit yang akan diakumulasikan di kolam UPAL. Tiga kolam terakhir digunakan sebagai kolam pemeliharaan ikan salah satunya ikan mujair, sebagai bioindikator. Ikan mujair dikolam itu dapat hidup namun belum diketahui bagaimana histologi dan anatomi organnya, sehingga perlu kajian histologis. Rancangan penelitian yang digunakan Rancangan Acak Lengkap dengan pengambilan sampel ikan mujair pada dua titik pengambilan dari area lagoon. Sampel ikan mujair diambil sebanyak 8 kali sebagai ulangan, dari setiap kolam yaitu kolam nomor 2 B dan kolam nomor 3 . Variabel yang diamati adalah kandungan timbal $(\mathrm{Pb})$ pada daging ikan dan kerusakan jaringan pada organ lambung . Rerata kandungan timbal dalam daging ikan dari kolam 2B sebesar 1,85 mg/kg, sedangkan dari kolam 3 sebesar 1,24 mg/kg. Jumlah sel dengan inti karyoreksis dan jaringan yang mengalami desquamasi sel epitel pada lambung ikan mujair (O. mossambicus) dari kolam 3 lebih rendah secara nyata dibandingkan di kolam 2B. Peralihan dari kolam 2B ke kolam 3 mengurangi kandungan timbal dan kerusakan histologis.
\end{abstract}

\section{Kata Kunci: mujair, lambung, logam berat, $\mathrm{Pb}$}

\section{ABSTRACT}

Nusa Dua is a tourism area with a comprehensive and integrated design for international class tourist accommodation. Liquid waste is managed in an integrated Wastewater Management Unit (UPAL) by PT. ITDC. Hotels dispose of their liquid waste through collection pits which will be accumulated in UPAL ponds. The last three ponds are used as fish rearing ponds as bioindicator. The tilapia fish in the pond can live but it is not known how the histology and anatomy of the organs are, therefore, histological study is needed. Eight samples were taken radomly from each pond, namely pool number $2 \mathrm{~B}$ and pool number 3. The variables observed were the lead $(\mathrm{Pb})$ content in fish meat and tissue damage in the stomach organs. The average lead content in fish meat from pond $2 \mathrm{~B}$ was $1.85 \mathrm{mg} / \mathrm{kg}$, while from pond 3 was $1.24 \mathrm{mg} / \mathrm{kg}$. The number of cells with karyorrhoeic nuclei and tissue desquamated epithelial cells in the stomach of tilapia fish (O. mossambicus) from pond 3 was significantly lower than in pond $2 \mathrm{~B}$. Transition from pond $2 \mathrm{~B}$ to pond 3 reduced lead content and histological damage. 


\section{Keywords: Oreochromis mossambicus, stomach, heavy metal, Pb}

\section{PENDAHULUAN}

Sektor pariwisata di Provinsi Bali memiliki peran yang cukup besar yaitu hampir $75 \%$ dalam menunjang perkembangan perekonomian (Rasmini, 2014). Kawasan Nusa Dua merupakan salah satu kawasan pariwisata di Bali yang berada di wilayah PT. Indonesia Tourism Development Corporation (ITDC). Menurut Sudipa dan Mahendra (2009) industri yang berwawasan lingkungan harus memiliki Water Treatment Recycle Process, dimana limbah yang dihasilkan tidak layak dibuang langsung ke lingkungan, namun harus diolah terlebih dahulu dan sebaiknya dipergunakan kembali untuk penyiraman kebun sebagai upaya penghematan air atau dapat dibuang kembali ke lingkungan tanpa menimbulkan dampak pencemaran.

Hotel - hotel yang berada di kawasan Nusa Dua membuang limbah cairnya di collection pit (kolam pembuangan) masing - masing yang kemudian akan dipompa ke saluran pipa limbah utama dan akan terkumpul di Lagoon yang berada di kawasan UPAL (Unit Pengolahan Air Limbah) PT. ITDC (Rasmini, 2014). Sistem pengolahan limbah di UPAL PT. ITDC Nusa Dua Bali menggunakan 5 kolam pengolahan limbah. Kolam 1A (kolam anerobik), kolam 1B (kolam anaerobik), kolam 2A (kolam fakultatif), kolam 2B (kolam fakultatif) dan kolam 3 (kolam pematangan) (Diniari dkk., 2014). Diniari dkk, (2014) menambahkan bahwa di kolam 2B dan 3 pemeliharaan ikan air tawar yaitu ikan nila dan mujair yang dijual kepada pengepul untuk digunakan sebagai pakan ternak.

Limbah cair yang dihasilkan dari usaha perhotelan tidak menutup kemungkinan mengandung bahan pencemar berbahaya seperti logam berat. Menurut Salve dan Sonwane (2015) logam berat digunakan dalam produk kosmetik sebagai tabir surya dan pigmen pewarnaan yang biasa digunakan dalam produk cat kuku, pelembab, sabun, shampo, pembersih, lipstik, krim wajah, bedak dan cat rambut. Menurut Nurmalasari (2016) timbal terkandung dalam cat rambut, lipstik (Ariyani dan Yugatama, 2017) dan krim wajah (Erasiska dkk, 2017). Menurut Sahetapy (2011) logam berat dengan konsentrasi yang tinggi dalam tubuh makhluk hidup akan mengganggu aktivitas enzim. Menurut Badan Standarisasi Nasional Indonesia (2009) mengenai batas maksimum cemaran logam berat dalam pangan batas maksimum $\mathrm{Pb}$ yang terkandung dalam ikan adalah sebesar $0,3 \mathrm{mg} / \mathrm{kg}$.

Berdasarkan hasil pengujian laboratorium pada bulan Agustus 2013 sifat fisik air limbah di UPAL PT. ITDC pada kolam 2B meliputi suhu sebesar $29,9^{\circ} \mathrm{C}$, zat padat terlarut (TDS) sebesar $2130 \mathrm{mg} / \mathrm{l}$, dan zat padat tersuspensi sebesar $38 \mathrm{mg} / \mathrm{l}$. Sifat fisik air pada kolam 3 meliputi suhu sebesar $29,1^{\circ} \mathrm{C}$, zat padat terlarut (TDS) sebesar $2220 \mathrm{mg} / \mathrm{l}$, dan zat padat tersuspensi sebesar 30 mg/l (Diniari dkk., 2014). Namun tidak ada data terhadap kandungan logam timbal dan struktur histologi lambung ikan mujair (O. mossambicus) yang hidup di kolam UPAL PT. ITDC.

Tujuan penelitian ini adalah untuk mengetahui kandungan timbal $(\mathrm{Pb})$ pada daging dan struktur histologi ikan mujar $(O$. mossambicus) yang hidup di kolam UPAL PT. ITDC.

\section{METODE PENELITIAN}




\section{Pengambilan Sampel Ikan}

Pengambilan sampel ikan mujair akan dilakukan dengan menjaring langsung pada lokasi dan diurutkan dengan undian. Pengambilan sampel pada setiap kolam dilakukan di 8 titik yang berbeda dengan jarak yang relatif sama. Penentuan pengambilan titik juga dilakukan secara undi. Pada setiap titik diambil satu ekor ikan, sehingga total pengambilan sampel sebanyak delapan ekor. Ikan yang diperoleh diidentifikasi berdasarkan berat dan panjang sesuai kategori yang ditentukan. Ikan dieutanasi dengan memasukkan ikan ke dalam ice box yang berisi es, selanjutnya dilakukan proses nekropsi pada ikan. Kemudian organ lambung dimasukkan ke dalam botol vial yang berisi larutan NBF $10 \%$.

\section{Pembuatan Preparat}

Pembuatan preparat histologi organ lambung ikan mujair (O. mossambicus) menggunakan metode embedding dan diiris setebal $5 \mu \mathrm{m}$ dengan pewarnaan hematoxylin-eosin, mengikuti metode baku histologi (Tjarta, 1992).

\section{Plasma Emission}

Penentuan kadar timbal menggunakan daging ikan mujair di bagian dekat insang, dilakukan di Laboratorium Analitik Fakultas Kelautan dan Perikanan Universitas Udayana. Metode pengujian berdasarkan metode Plasma Emission dengan pembacaan menggunakan alat Spektrofotometer Serapan Atom (SSA) dari Jovita (2018).

\section{Pengamatan}

Pengamatan sayatan histologi lambung dilakukan dibawah mikroskop cahaya dengan bantuan kamera opticlab dengan perbesaran 400x. Parameter yang diamati adalah jumlah sel yang mengalami kerusakan berupa inti piknotik, inti karyoreksis, inti karyolisis, degenerasi melemak, degenerasi hidropik, hemoragi, kongesti, infiltrasi sel radang dan desquamasi sel epitel. Selanjutnya dilakukan penghitungan jumlah kerusakan sel dengan menggunakan aplikasi Image Raster.

\section{Analisis Data}

Hasil data pengamatan preparat histologi lambung ikan dianalisis dengan analisis Independent Sample T Test dengan menggunakan SPSS v20.0 for Windows pada taraf nyata $(\alpha)<0,05$.

\section{HASIL DAN PEMBAHASAN}

Hasil uji kandungan logam timbal pada daging ikan yang hidup di kolam 2B dan kolam 3 disajikan pada Tabel 1.

Tabel 1. Hasil Uji Kadar Timbal pada Daging Ikan Mujair yang Hidup di Kolam UPAL.

\begin{tabular}{|c|c|c|}
\hline \multirow[b]{2}{*}{ Ikan ke - } & Kolam 2B & Kolam 3 \\
\hline & $\begin{array}{c}\text { Kadar Pb } \\
(\mathrm{mg} / \mathrm{kg})\end{array}$ & $\begin{array}{c}\text { Kadar Pb } \\
(\mathrm{mg} / \mathrm{kg})\end{array}$ \\
\hline $1($ P $)$ & 2,14 & 0,97 \\
\hline $2($ ( $)$ & 2,62 & 1,05 \\
\hline 3 (O) & 1,08 & 0,52 \\
\hline $4($ (P) & 1,59 & 0,75 \\
\hline $5($ (q) & 1,74 & 0,70 \\
\hline $6(\overbrace{}^{\lambda})$ & 2,42 & 0,97 \\
\hline $7\left(0^{3}\right)$ & 1,81 & 2,36 \\
\hline $8(\widehat{\jmath})$ & 1,38 & 2,60 \\
\hline Rata-rata & 1,85 & 1,24 \\
\hline
\end{tabular}

Berdasarkan hasil pengamatan histologi lambung ditemukan kerusakan sel berupa inti yang mengalami piknotik, karyoreksis, karyolisis, degenerasi melemak, kongesti, hemoragi, desquamasi sel epitel dan infiltrasi sel radang (Tabel 2). Hasil perhitungan statistik Independent Sample T-Test menunjukkan kerusakan berupa karyoreksis pada inti sel dan 
desquamasi sel epitel pada ikan yang hidup dikolam 3 lebih rendah secara nyata dibandingkan di kolam 2B. Kerusakan histologi berupa piknotik, karyolisis, degenerasi melemak, kongesti, hemoragi, dan infilrasi sel radang tidak berbeda nyata. Secara histologi inti yang mengalami piknotik yang ditandai dengan adanya penebalan pada inti sel seperti pada Gambar 1 dan 6. Inti yang mengalami karyoreksis yang ditandai dengan pecahnya inti sel seperti pada Gambar 1 dan 6. Inti yang mengalami karyolisis yang ditandai dengan hilangnya inti sel seperti pada Gambar 1 dan 6. Sel yang mengalami degenerasi melemak yang memperlihatkan membesarnya sitoplasma karena terpenuhi dengan lemak dapat diamati pada Gambar 2 dan 6.

Kongesti dan hemoragi yang ditandai dengan penumpukan sel darah merah di dalam dan diluar saluran pembuluh darah dapat diamati pada Gambar 3, 4, 6 dan 8. Infiltrasi sel radang yang menunjukkan menumpuknya sel limfosit pada jaringan dapat diamati pada Gambar 3 dan 7. Deskuamasi sel epitel yang ditunjukkan dengan lepasnya sel - sel epitel dapat diamati pada Gambar 5 dan 9.

Tabel 2. Hasil Analisis Rata-rata Kerusakan Sel Lambung Ikan Mujair ( $O$. mossambicus) yang Hidup di Kolam UPAL PT. ITDC.

\begin{tabular}{ccc}
\hline Parameter & \multicolumn{2}{c}{ Kelompok } \\
\cline { 2 - 3 } & Kolam 2B & Kolam 3 \\
\hline Piknotik (sel) & $40,13 \pm 39,10^{\mathrm{a}}$ & $66,86 \pm 31,48^{\mathrm{a}}$ \\
Karyoreksis (sel) & $19,60 \pm 9,34^{\mathrm{a}}$ & $9,99 \pm 5,90^{\mathrm{b}}$ \\
Karyolisis (sel) & $7,22 \pm 5,66^{\mathrm{a}}$ & $4,84 \pm 2,30^{\mathrm{a}}$ \\
Degenerasi Hidropik (sel) & $0,00 \pm 0,00^{\mathrm{a}}$ & $0,00 \pm 0,00^{\mathrm{a}}$ \\
Degenerasi Lemak (sel) & $36,21 \pm 33,10^{\mathrm{a}}$ & $23,99 \pm 11,71^{\mathrm{a}}$ \\
Kongesti (\%) & $43,63 \pm 11,76^{\mathrm{a}}$ & $44,88 \pm 15,27^{\mathrm{a}}$ \\
Hemoragi (\%) & $23,38 \pm 10,34^{\mathrm{a}}$ & $19,00 \pm 9,83^{\mathrm{a}}$ \\
Infiltrasi Sel Radang (\%) & $44,38 \pm 17,61^{\mathrm{a}}$ & $59,63 \pm 13,62^{\mathrm{a}}$ \\
Desquamasi Sel Epitel (\%) & $49,63 \pm 23,29^{\mathrm{a}}$ & $14,50 \pm 5,15^{\mathrm{b}}$ \\
\hline
\end{tabular}

Keterangan: Huruf yang berbeda pada kolom dan baris yang sama menunjukkan berbeda nyata $(\mathrm{p} \leq 0,05)$

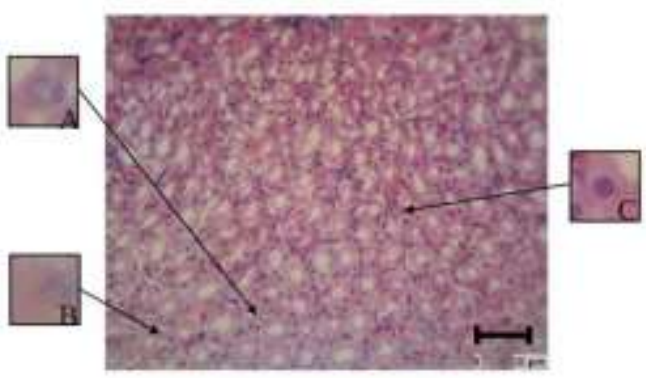

Gambar 1. Gambaran Histologi Lambung Ikan Mujairyang Hidup di Kolam 2B. Keterangan (A) Karvoreksis. (B) Karvolisis. (C)

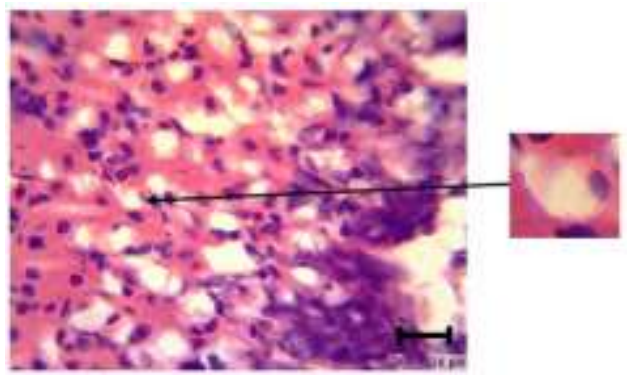

Gambar 2. Degenerasi Lemak yang Terjadi pada Ikan Mujair yang Hidup di Kolam 2B (Perbesaran 400x). 


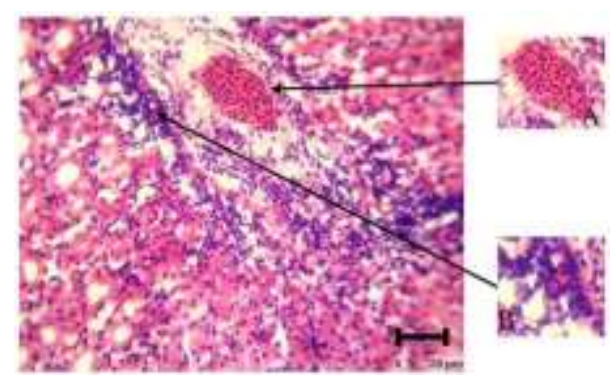

Gambar 3. Gambaran Histologi Lambung Ikan Mujair yang Hidup di Kolam 2B yang Mengalami (A) Kongesti dan (B) Infiltrasi Sel Radang

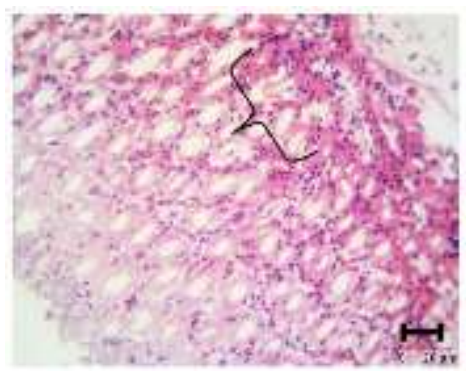

Gambar 4. Hemoragi yang Terjadi pada Ikan Mujair yang Hidup di Kolam 2B (Perbesaran 400x).

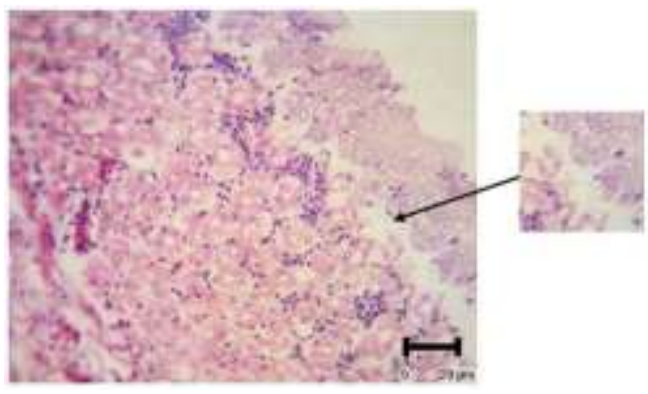

Gambar 5. Desquamasi Sel Epitel yang Terjadi pada Ikan Mujair yang Hidup di Kolam 2B (Perbesaran 400x).

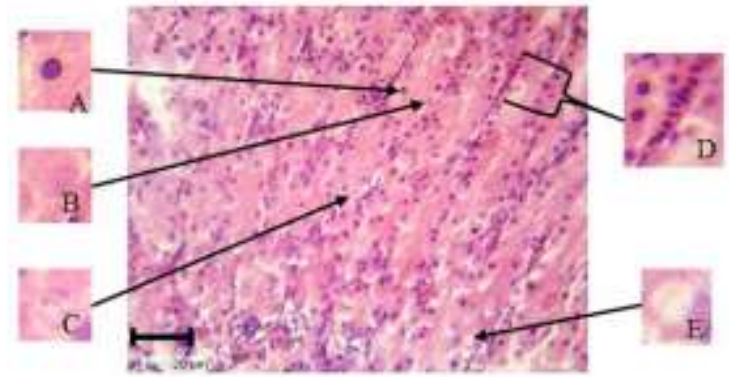

Gambar 6. Gambaran Histologi Lambung Ikan Mujairyang Hidup di Kolam 3. Keterangan (A) Piknotik (B) Karyolisis (C) Karyoreksis (D) Hemoragi (E) Degenerasi Lemak (Perbesaran

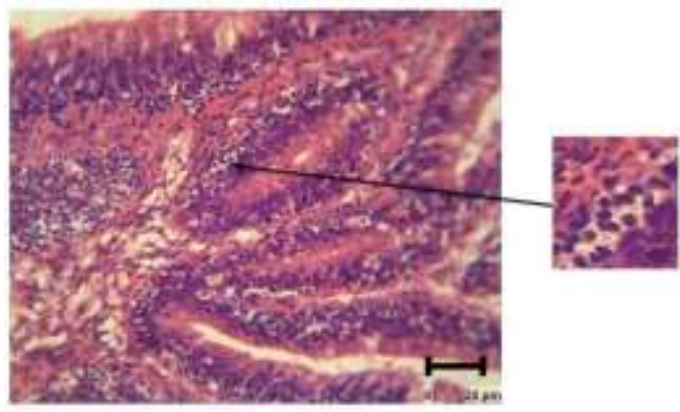

Gambar 7. Infiltrasi Sel Radang yang Terjadi padaIkan Mujair yang Hidup di Kolam 3 (Perbesaran 400x).

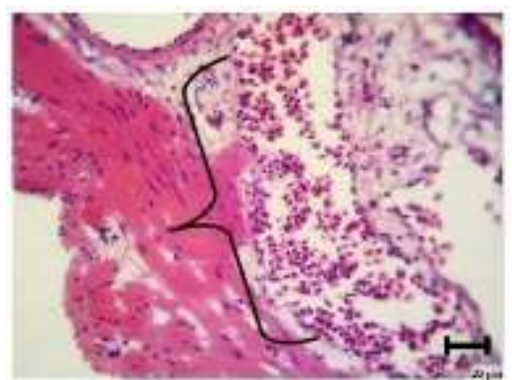

Gambar 8. Kongesti yang Terjadi pada Ikan Mujair yang Hidup di Kolam 3 (Perbesaran 400x). 


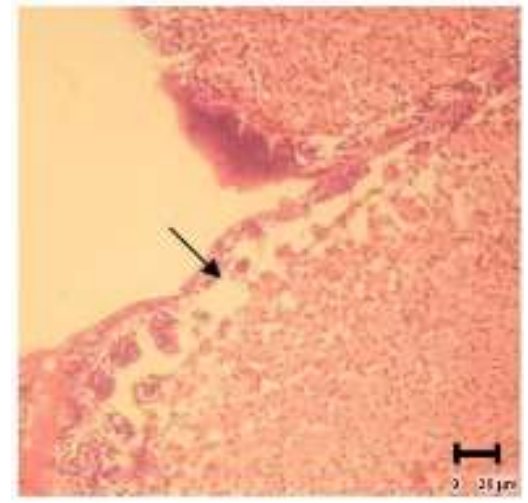

Gambar 9. Desquamasi Sel Epitel yang Terjadi pada Ikan Mujair yang Hidup di Kolam 3 (Perbesaran 400x).

Kandungan timbal yang didapatkan dari hasil pengujian menggunakan metode plasma emission pada daging ikan mujair yang hidup di kolam 2B dan kolam 3 melebihi baku mutu yang telah ditentukan. Baku mutu yang telah ditentukan berdasarkan keputusan menteri lingkungan hidup no. 51 tahun 1995 adalah sebesar 0,03 mg/kg. Berdasarkan data pada Tabel 1 rata-rata kandungan timbal ikan di kolam 2B lebih besar dibandingkan dengan ikan di kolam 3. Hal ini disebabkan karena kolam 3 merupakan kolam terakhir pada proses penyaringan limbah di UPAL ITDC sehingga kandungan timbal pada ikan lebih sedikit.

Penyerapan timbal oleh ikan dapat dilakukan melalui 3 cara yaitu dengan respirasi melalui insang, melalui permukaan tubuh dan dari makanan atau air melalui sistem pencernaan (Murtiani, 2003). Timbal yang masuk melalui pencernaan ikan akan terikat di dalam tubuh dengan gugus $\mathrm{S}-\mathrm{H}$ dalam protein, sehingga menyebabkan kerja enzim terhambat dan mengganggu sintesis hemoglobin (Nurfitriani, 2017). Yulaipi (2013) menambahkan bahwa timbal yang masuk ke dalam tubuh akan berikatan dengan erotrosit di dalam peredaran darah. Ikan akan menyerap timbal dan mengakumulasi di dalam tubuhnya karena logam berat tidak dapat di sintesis oleh tubuh. Hal ini yang menyebabkan kandungan timbal di daging ikan lebih besar dibandingkan dengan kandungan timbal di air kolam 2B sebesar 0,061 mg/kg dan kolam 3 sebesar 0,057 mg/kg.

Berdasarkan hasil statistik, kerusakan berupa karyoreksis pada inti sel dan desquamasi sel epitel pada ikan yang hidup di kolam 3 lebih rendah secara nyata dibandingkan di kolam 2B. Hasil ini menunjukkan kandungan bahan pencemar di air kolam 2B lebih berpengaruh dalam menyebabkan kerusakan tersebut dibandingkan dengan kolam 3. Hal tersebut sesuai dengan hasil uji kualitas air yaitu kandungan logam timbal $(\mathrm{Pb})$ di kolam $2 \mathrm{~B}$ adalah $0,061 \mathrm{mg} / \mathrm{kg}$ dan di kolam 3 0,057 $\mathrm{mg} / \mathrm{kg}$. Karyoreksis merupakan proses inti sel menuju nekrosis. Nekrosis adalah sel atau jaringan yang mati akibat jejas saat individu masih hidup (Silvia dan Agus, 2011). Menurut Kahfi (2016) nekrosis dapat timbul karena adanya kandungan logam pada air yang diserap ikan dan mengendap pada daging.

Robbins (2006) menegaskan bahwa timbal yang masuk ke dalam tubuh makhluk hidup akan menjadi radikal bebas dan dapat menyebabkan rangsangan patologi seperti jejas reversible dan irreversible seperti nekrosis. Masuknya radikal bebas ke dalam tubuh makhluk hidup juga dapat menyebabkan stres oksidatif yang mengakibatkan ketidakseimbangan molekul - molekul di dalam selsehingga sel akan mengalami degenerasi (Janardani dkk, 2018). Sel yang mengalami degenerasi, jika terpapar bahan toksik dalam jangka waktu lama dapat menyebabkan kematian sel atau nekrosis. Nekrosis sel juga dapat disebabkan oleh kekurangan oksigen, kandungan logam 
ataupun perubahan suhu yang ekstrim (Sukarni dkk, 2012).

Menurut Salmin (2005) kandungan BOD dan COD berbanding terbalik dengan DO (Dissolved Oxigen) dimana semakin tinggi kadar DO maka semakin tinggi kandungan oksigen yang terlarut di dalam air. Berdasarkan hasil analisis BOD dan COD di kolam 2B adalah sebesar 83,7 $\mathrm{mg} / \mathrm{L}$ dan $120 \mathrm{mg} / \mathrm{L}$ dan di kolam 3 sebesar 69,2 $\mathrm{mg} / \mathrm{L}$ dan $110 \mathrm{mg} / \mathrm{L}$, didapatkan hasil yang melebihi standar mutu. Tingginya COD dan BOD menyebabkan penurunan DO, artinya kadar oksigen di dalam air menurun (rendah). Penurunan kadar oksigen perairan menyebabkkan ikan mengalami nekrosis sel pada lambung.

Jaringan epitel yang mengalami desquamasi pada lambung ikan mujair penelitian ini disebabkan adanya sel yang mengalami nekrosis. Menurut Takashima dan Hibiya (1995) pada sel - sel yang mengalami nekrosis, terjadi peningkatan volume (hipertropi) sehingga mengakibatkan sel terlepas satu dengan yang lainnya. Gambaran histologi jaringan epitel yang mengalami desquamasi pada lambung ikan mujair di kolam 2B dan kolam 3 dapat dilihat pada Gambar 5 dan 9.

Hipertropi juga dapat terjadi akibat terjadinya penyumbatan senyawa yang bersifat toksik, meskipun dalam jumlah yang sedikit, dapat terjadi proses bioakumulasi sehingga tubuh ikan terkontaminasi cukup lama. Hal ini diduga karena adanya kandungan timbal dalam tubuh ikan dengan konsentrasi yang melebihi baku mutu yang telah ditetapkan menurut keputusan menteri lingkungan hidup no. 51 tahun 1995 yaitu sebesar 0,03 $\mathrm{mg} / \mathrm{kg}$. Desquamasi sel epitel atau pelepasan sel epitel di lambung dapat mengganggu penyerapan nutrisi oleh ikan yang akan menurunkan laju pertumbuhan ikan. Yulaipi (2013) menyebutkan bahwa ikan mujair (O. mossambicus) berpotensi mengakumulasi logam berat dan semakin lama pemaparan terjadi akan berpengaruh terhadap laju pertumbuhan.

Timbal yang masuk ke dalam tubuh dan memasuki peredaran darah menyebabkan peningkatan radikal bebas dan menimbulkan stres oksidatif di dalam tubuh. Jin et al., (2008) melaporkan bahwa pemberian logam berat timbal asetat dosis $10 \mathrm{mg} / \mathrm{kg}$ BB secara oral pada mencit menyebabkan timbulnya stres oksidatif. Selanjutnya stres oksidatif menyebabkan terbentuknya radikal bebas seperti Reactive Oxygen Species (ROS) yang memicu rusaknya molekul di dalam sel. Selain inti karyoreksis dan desquamasi sel epitel juga ditemukan kerusakan berupa degenerasi melemak, hemoragi, kongesti, karyolisis, piknotik serta infiltrasi sel radang. Degenerasi melemak merupakan akumulasi lemak di dalam sitoplasma sehingga mendesak inti sel ke tepi sitoplasma (Assiam dkk, 2014) (Gambar 2 dan 6). Menurut Fahmi dkk (2015), umumnya degenerasi melemak terjadi karena bahan toksik, disfungsi nutrisi dan umur tua. Kurniawan (2014) menegaskan bahwa degenerasi melemak dapat terjadi akibat bahan toksik yang menghambat kerja enzim.

Hemoragi dan kongesti pada ikan yang hidup di kolam 2B dan 3 (Gambar 4 dan 6) dapat terjadi karena adanya infeksi ataupun cedera (Masri dan Arifuddin, 2013). Menurut Jamin dan Erlangga (2016) amonia merupakan salah satu senyawa yang dapat menyebabkan gangguan pada sel sehingga menyebabkan cedera dan infeksi sel. Kadar amonia yang tinggi pada air limbah yang berada di kolam 2B dan 3 yaitu sebesar $14,4 \mathrm{mg} / \mathrm{L}$ dan $12 \mathrm{mg} / \mathrm{L}$, dapat masuk ke dalam tubuh ikan mujair dalam 
bentuk $\mathrm{NH}_{3}$ kemudian akan berdifusi ke jaringan. $\mathrm{NH} 3$ yang masuk ke jaringan akan dianggap sebagai benda asing sehingga terjadi peradangan yang diakibatkan oleh infiltrasi sel radang pada lambung ikan (Gambar 3, 7 dan 8).

\section{KESIMPULAN}

Rata - rata kandungan timbal dalam daging ikan mujair (O. mossambicus) yang hidup di kolam 2B UPAL PT. ITDC sebesar $1,85 \mathrm{mg} / \mathrm{kg}$, sedangkan yang hidup di kolam 3 sebesar 1,24 mg/kg. Jumlah sel yang intinya mengalami karyoreksis dan jaringan yang mengalami desquamasi sel epitel pada lambung ikan mujair ( $O$. mossambicus) yang hidup di kolam 3 UPAL PT. ITDC lebih rendah secara nyata dibandingkan di kolam 2B.

\section{SARAN}

Diperlukan penelitian lebih lanjut penyebab tingginya kandungan timbal di UPAL PT. ITDC Nusa Dua Bali. Pemanfaatan ikan yang dipelihara di kolam UPAL PT. ITDC Nusa Dua Bali harus dibatasi.

\section{UCAPAN TERIMA KASIH}

Terima kasih kepada UPAL (Unit Pengelolaan Air Limbah) PT. ITDC Nusa Dua Bali yang telah mengizinkan instansinya sebagai lokasi untuk penelitian.

\section{DAFTAR PUSTAKA}

Ariyani, L. D., Yugatama, A. 2017. Analisis Kandungan Timbal $(\mathrm{Pb})$ pada Lipstik yang Beredar di Kota Surakarta. Pengembangan dan Aplikasi Nanomedicine dalam Bidang Kesehatan 2(1):87-91.

Assiam, N., Setyawati, I., Sudirga, S. K. 2014. Pengaruh Dosis dan Lama
Perlakuan Ekstrak Daun Kaliandra Merah (Calliandra calothyrsus Meissn.) tergadap Struktur Histologi Ginjal Mencit (Mus musculus L.). Jurnal Simbiosis II. 2(6):236-246.

Badan Standardisasi Nasional. 2009. SNI 7387 : 2009 Tentang Batas Maksimum Cemaran Logam Berat dalam Pangan. Jakarta: BSN.

Diniari, N. A., Anggreni, A. A. M. D., dan Arnata, I. W. 2014. Analisis Kandungan Angka Lempeng Total dan Eschericia coli pada Ikan Nila dan Mujair di Unit Pengolahan Air Limbah (UPAL) PT. Indonesia Tourism Development Corporation (ITDC). Hal:101-108

Erasiska, Subardi, B., Hanifah, T. A. 2015. Analisis Kandungan Logam Timbal, Kadmium dan Merkuri dalam Produk Krim Pemutih Wajah. JOM FMIPA 2(1):123-129.

Fahmi. M., Yudha, F., Dwinna, A., Hamdani, B., Siti, A., Muhammad, H. 2015. Gambaran Histopatologis Hati Tikus (Rattus novergicus) yang Diinfeksi Trypanosoma evansi setelah Pemberian Ekstrak Kulit Batang Jaloh (Salix tetrasperma Roxb). Jurnal Medika Veterinaria. 9(2):141-145.

Jamin, J., Erlangga E. (2016). Pengaruh limbah organik golongan organofosfat terhadap benih ikan nila gift (Oreochromis niloticus, Bleeker): analisis histologi hati dan insang. Acta Aquatica: Aquatic Sciences Journal. 3(2): 46-53.

Janardani, N. M. K., Berata, I. K., Kardena, I. M. 2018. Studi Histopatologi dan Kadar Timbal pada Ginjal Sapi Bali di Tempat Pembuangan Akhir Suwung Denpasar. Indonesia Medicus Veterinus. 7(1):42-50. 
Jin, X., Ling-jun, L., Chen W., Xiao-feng, W., Wen-yu, F. and Li-hong, X. 2008. Lead Induces Oxidative Stress, DNA Damage and Alteration of P53, Bax and Bcl-2 Expressions in Mice. Food and Chemical Toxicology 46.1488-1494.

Jovita, D. 2018. Analisis Unsur Makro (K, $\mathrm{Ca}, \mathrm{Mg}$ ) Mikro (Fe, $\mathrm{Zn}, \mathrm{Cu}$ ) pada Lahan Pertanian dengan Metode Inductively Coupled Plasma Optical Emission Spectrofotometry (ICPOES). Skripsi. Universitas Lampung.

Kahfi, E. K., Morina, R., Iesje, L. 2016. Histopatologi Hati dan Ginjal Ikan Lele Dumbo (Clarias gariepinus) yang Diberi Pakan Simplisia Kulit Buah Manggis (Garcinia mangostana L). Jurnal Kelautan. $4(2): 49-56$.

Kurniawan, I. W. A. Y., Wiratmini, N. I., Sudatri, N. W. 2014. HistoloGI Hati Mencit (Mus musculus L.) yang Diberikan Ekstrak Daun Lamtoro (Leucaena leucocephala). Jurnal Simbiosis II. 2(5):226-235.

Masri. M., Arifuddin, A. 2013. Deteksi Koi Harpes Virus (KHV) Pada Ikan Mas Koi (Cyprinus Carpio L) Dengan Menggunakan Metode Aplikasi Polym Erase Chain Reaction(PCR). Jurnal Teknosains. 7(2):189-200.

Murtiani. L. 2003. Analisis Kadar Timbal $(\mathrm{Pb})$ pada Ekstrak Kerang Darah (Anadara granosa L.) di Muara Sungai Tambak Oso Sedati-Sidoarjo. Skripsi. Universitas Negeri Surabaya.

Nurfitriani, S. 2017. Bioakumulasi Logam Berat Timbel $(\mathrm{Pb})$ pada Ikan Nila (Oreochromis niloticus Linn.) di Tambak Sekitar Muara Sungai Pangkajene Kabupaten Pangkajene dan Kepulauan (Pangkep). Skripsi. Universitas Hasanuddin.
Nurmalasari, D. 2016. Analisis Kadar Logam Timbal $(\mathrm{Pb})$ pada Cat Rambut dengan Variasi Zat Pengoksidasi Menggunakan Destruksi Basah Secar Spektroskopi Serapan Atom (SSA). Skripsi. Universitas Islam Negeri Maulana Malik Ibrahim Malang.

Rasmini, N. W. 2014. Kontrol Pompa Air Limbah Menggunakan Sensor WLC Omron 61F-G. Jurnal Logic 14(3):144-150

Robbins, S. L., Kumar, V. 2006. Buku Ajar Patologi 1 (Basic Pathology). Jakarta :EGC.

Sahetapy, J. M. 2011. Toksisitas Logam Berat Timbal $(\mathrm{Pb})$ dan Pengaruhnya pada Konsumsi Oksigen dan Respon Hematologi Juvenil Ikan Kerapu Macan. Thesis. Pasca Sarjana IPB, Bogor.

Salmin. 2005. Oksigen Terlarut (Do) dan Kebutuhan Oksigen Biologi (Bod) Sebagai Salah Satu Indikator untuk Menentukan Kualitas Perairan. Oseana. 30(3):21-26.

Salve, K. S., Sonwane, N. S. 2015. Detection of Heavy Metals in Cosmetics. World Journal of Pharmaceutical Research 4(4):13681372.

Silvia, A., Agus, M. 2011. Analisis Citra Ginjal untuk Identifikasi Sel Piknosis dan Sel Nekrosis. Jurnal Neutrino. 4(1):48-66.

Sudipa, N., Mahendra, N. S. 2009. Studi Kualitas Hasil Pengolahan Air Limbah Salah Satu Hotel Berbintang di Bali. Ecotrophic 1(2).

Sukarni, Maftuch, Nursyam, H. 2012. Kajian Penggunaan Ciprofloxacin terhadap Histologi Insang dan Hati Ikan Botia (Botia macracanthus, Bleeker) yang Diinfeksi Bakteri Aeromonas hydrophila. The Journal 
of Experimental Life Science. 2(1):612.

Takashima, F, Hibiya, T. 1995. An Atlas of Fish Histology. Normal and Phatological Features. Second Edition. Kondansha LTD. Tokyo. Japan.

Tjarta, A. 1992. Prosedur Baku Pemeriksaan Patologi. Fakultas Kedokteran Universitas Indonesia. Jakarta.

Yulaipi. S., Aunurohim. 2013. Bioakumulasi Logam Berat Timbal $(\mathrm{Pb})$ dan Hubungannya dengan Laju Pertumbuhan Ikan Mujair (Oreochromis mossambicus). Jurnal Sains dan Seni Pomits 2(2):23373520. 